\title{
On the roads of Spain: Andrei Vizanti, the first Romanian student in Madrid (1865-1868)
}

\section{En las carreteras de España: Andrei Vizanti, el primer estudiante rumano en Madrid (1865-1868)}

\author{
IOSif IULIAN ONCESCU \\ Universitatea Valahia din Târgoviște, Rumania \\ iulian.oncescu@valahia.ro \\ https://orcid.org/0000-0002-3626-5612
}

Fecha de recepción: 04-12-2019

Fecha de aceptación: 16-03-2020

\begin{abstract}
In the process of educating modern Romanian elites, especially after the Unification of the Romanian Principalities (1859), two young Romanian students journeyed to faraway Spain. Their names were Andrei Vizanti and Ștefan Vârgolici, selected as scholars from the state of Romania, in the autumn of 1864, to study at the Central University (Madrid, Spain), for a period of four years. Of the two, only Andrei Vizanti remained in the Spanish capital, while Ștefan Vârgolici, after a short stay in Madrid (in 1865), left for Paris. After three years of study (1865-1868), in June 1868, Andrei Vizanti obtained the title of Graduate of the Faculty of Philosophy and Letters at the Central University, becoming the only Romanian graduate of a Spanish university until the second half of the $20^{\text {th }}$ century.
\end{abstract}

Key words: Andrei Vizanti, Romanian student, Central University, Romanian-Spanish relationships.

Toponyms: Spain, Romania.

Period: 1865-1868.

\section{RESUMEN}

En el proceso de formación de las élites rumanas modernas, especialmente después de la Unificación de los Principados Rumanos (1859), dos de los jóvenes estudiantes rumanos llegaron a la lejana España. Es el caso de Andrei Vizanti y Ştefan Vârgolici, quienes fueron seleccionados como académicos del estado rumano en el otoño de 1864 para estudiar en la Universidad Central (Madrid, España), por un período de cuatro años. De estos, sólo Andrei Vizanti permaneció en la capital española, mientras que Ştefan Vârgolici, después de una breve parada en Madrid (en 1865), partió para París. Después de tres años de estudio (1865-1868), en junio de 1868, Andrei Vizanti obtuvo el título de Licenciado en La Facultad de Filosofía y Letras de la Universidad Central, sendo el único graduado de una universidad española hasta la segunda mitad del siglo XX. 
Palabras clave: Andrei Vizanti, estudiante rumano, Universidad Central, relaciones rumanoespañolas.

Topónimos: España, Rumanía.

Período: 1865-1868

\section{INTRODUCTION}

Establishing universities in Romanian (Iași-1860, Bucharest-1864) did not implicitly mean the fact that these could ensure the education of the Romanian intellectual elite ${ }^{1}$. Under these circumstances, the foreign universities, especially those in Western Europe, continued even in this era to have, for a long period of time, a monopoly of the education of the autochthonous elite ${ }^{2}$. Thus, a major role in the process of the education of the Romanian intellectuals in the second half of the XIX century and even in the first half of the XX century, especially in the universities of France, Germany and Austria, was followed in the second plan by those in Belgium, Switzerland, Italy and Hungary, some of them studying in Spain, Greece or England ${ }^{3}$. In this context of the education of process of the modern Romanian elites, especially after the Unification of the Romanian Principalities (1859), two of the young studious Romanian men arrived in the faraway Spain, one of the studying there ${ }^{4}$.

Although few details are known about the intention of the Romanian authorities to send scholars to Spain, all clues clearly lead to the pro-Latin vision of Vasile Alexandrescu Urechia (1834-1901) who had directly known Spain in his youth (1857), he had been married to a Spanish woman (Francisca Josephine Dominique de Plano), he had made several trips to this country (1860-1861, 1867-1868), and had, after the death of his wife, kept in 1858 close ties to the Spanish intellectuals (Alfredo Adolfo Camus, Emilio Castelar). Certainly, these personal items, invoked by some of the contemporaries themselves, had a decisive

1 L. Năstasă, Itinerarii spre lumea savantă. Tineri români din spațiul românesc la studii în străinătate (18641944), Editura Limes, Cluj Napoca, 2006, pp. 66, 70.

2 Idem, "Rolul universităţilor occidentale în modernizarea şi europenizarea elitelor româneşti (1860-1918)", in Xenopoliana, VI, nr. 1-2, Iaşi, 1998, pp. 169-170.

3 Idem, Itinerarii spre lumea savantă..., pp. 91-92; Idem, "Rolul universităţilor occidentale..., p.172; I. Oncescu, România în politica orientală a Franței (1866-1878), Second Edition, revised and enlarged, Editura Cetatea de Scaun Târgoviște, 2010, p. 273 (In this hierarchy of foreign universities, where the Romanian elite was educated, France was on the first place, being the main source for Romanian bachelors and doctors in the second half of the XIX century and the first half of the XX century).

4 D. Berindei, "Spania în viziunea lui Mihail Kogălniceanu şi V. A. Urechia" in vol. Modernitate şi trezire naţională. Cultura naţională modernă. Studii şi eseuri, Editura Fundaţiei PRO, Bucureşti, 2003, pp. 230-231. Briefly, on the Spanish case (Hispanic Attempts) see L. Năstasă, Itinerarii spre lumea savantă..., pp. 315317. In the context of the ensemble of the history of the relationships between Romania and Spain, the direct contacts and convergences between the two countries had a great importance. But, in the first half of the XIX century, few Romanian travellers who passed through the territories of Europe from various reasons (economical and political, the desire to educate themselves and to learn abroad, the contact with other cultures and traditions) arrived in the Hispanic Peninsula. Thus, in 1846-1847, Spain would be directly acknowledged by historian Mihail Kogălniceanu (1817-1891) and ten years later, in 1857, by historian Vasile Alexandrescu Urechia who later made several visits in this country. Between the years 1865-1868, after obtaining a grant from University of lași (1864) through the support of his mentor, V. A. Urechia, Andrei Vizanti studied in the capital of Spain within the Faculty of Philosophy and Letters of the Central University - today Complutense University of Madrid (I. Oncescu, "Cunoaștere și descoperire: Spania în viziunea lui Mihail Kogălniceanu (1846-1847)", in Ș. Ștefănescu, C. Neagoe (eds.), Cultură, Istorie și Societate, VI, Editura Ars Docendi, București, 2017, pp. 327- 329). 
role in sending young men to study in Spain but, besides this, professor Vasile Alexandrescu Urechia had correctly noticed the necessity of having good knowledge of Spanish language and literature in the Romanian academic environment. Under these circumstances, starting with 1859, when he became director of the Ministry of Public Instruction in Moldova, V. A. Urechia has campaigned for sending Romanian students to study abroad, especially in neoLatin countries. Until 1864, no Romanian student had been sent to study in Spain, so there was no precedent in this respect. Perhaps the distance between the two countries was a factor, in addition to not knowing the Spanish education system, the lack of such initiatives. Thus, in the autumn of the year 1864, two of the students of Iași University, Andrei Vizanti and Ștefan Vârgolici were selected as scholars of Romania to study in the Central University (Madrid, Spain), for a period of four years. Out of the two, only Andrei Vizanti would become a bachelor of the Faculty of Philosophy and Letters, after three years of study in the capital of Spain (1865-1868) while Ștefan Vârgolici, after a short stay in Madrid (in 1865), he went to Paris, where he continued his studies 5 .

\section{ANDREI VIZANTI. A FEW BIOGRAPHICAL DETAILS AND THE MEANDERS OF DESTINY (1844-?)}

Andrei Vizanti was born in lasi, Moldova, on May 4, 1844. He came from a Greek family, his father, Andrei (Andricu) Vizanti, was brought to Moldova by Metropolitan Veniamin Costache being, according to some sources, a teacher of mathematics and religious music in lași and after 1827 he worked in the Moldavian Metropolitan Church. Later he was an engineer and the Moldavian ruler Mihail Sturdza (1834-1849) awarded him small boyar's ranks. Young Andrei Vizanti studied at the Central Gymnasium in Iasi where he was colleague with Ştefan G. Vârgolici.

Later, in the years 1863-1864, Andrei Vizanti would become colleague with the same Ștefan Vârgolici at Iași and together with him he would obtain a grant to study abroad for Madrid -the autumn of 1864). Andrei Vizanti studied, as scholar, in the period 1865-1868, at the Central University in Madrid becoming bachelor of the Faculty of Philosophy and Letters in 1868. In parallel with his studies, when he was in Spain, he developed an intense journalistic activity in Romania, but also in Spain (Buletinul Instrucțiunii Publice, Convorbiri Literare, Românul, La Reforma, La Enseñanza). After returning in Romanian, with the help of his mentor Vasile Alexandrescu Urechia (who had transferred to the University of Bucharest) he became substitute teacher (temporary) at lași University for the department of Romanian language, literature and history starting with the school year 1868-1869, department where he would stay for almost 30 years. He was involved in the Romanian political life as a member of the National Liberal Party, being elected by the party as deputy (1879), senator (1885) in the Romanian Parliament, and after the year 1890 he was even the vice-president of the

5 L. Rados, "Studenți și profesori ai Universității din lași la studii în străinătate (deceniul șapte al secolului XIX) (I)", in Historia Universitatis Iassiensis, I, 2010, Editura Universității Alexandru Ioan Cuza, Iași, 2010, pp. 90-92; D.V. Andronache, , Contribuția lui Andrei Vizanti la dezvoltarea relațiilor culturale româno-spaniole”, in S. L. Damean, M. Cârstea, M. Damean, L. Dindirică (coords.), Permanențele Istoriei. Profesorului Corneliu Mihai Lungu la 70 de ani, Editura Cetatea de Scaun, Târgoviște, 2013, p. 208; L. Năstasă, Itinerarii spre lumea savantă...,pp. 315-316. See especially for Andrei Vizanti's years of study in Madrid (1865-1868), Archivo Histórico Nacional, Madrid (henceforth AHN, Madrid), Universidades, Legajos 6887/1 (Seccción Filosofia y Letras, Expediente Vizanti Basilio Andrés, page not numbered); Universidades, 6896, exp. 1 y 2, pages not numbered; F. J. Juez y Galvez, "El primer alumno rumano de la Central (1865-1868). 'Acercando así la Romanía á la civilización de las demás naciones latinas'”, in Revista de Filología Románica, 2003, nr. 20, pp. 123-134; D. V. Andronache, op. cit., pp. 208-221. The Spanish names of the two Romanians as they appear in the archives are: Andrés A. Vizanti y Basilio și Esteban I. Vargolicin (AHN, Madrid, Universidades, 6887/1; F. J. Juez y Galvez, op. cit., p. 125). 
Senate. Other functions held by Andrei Vizanti until April 1899 when he emigrated to the United States following a scandal related to the embezzlement of funds were: President of the Romanian Society for the Teaching of the Romanian People, Iași Branch (1891), Chairman of the Theatrical committee, lași (1896). He published several brochures, among which the most important one was dedicated to the Metropolitan of Moldova, Veniamin Costache (1881) .

Figure 1. Photografy of Andrei Vizanti (1844 -?)

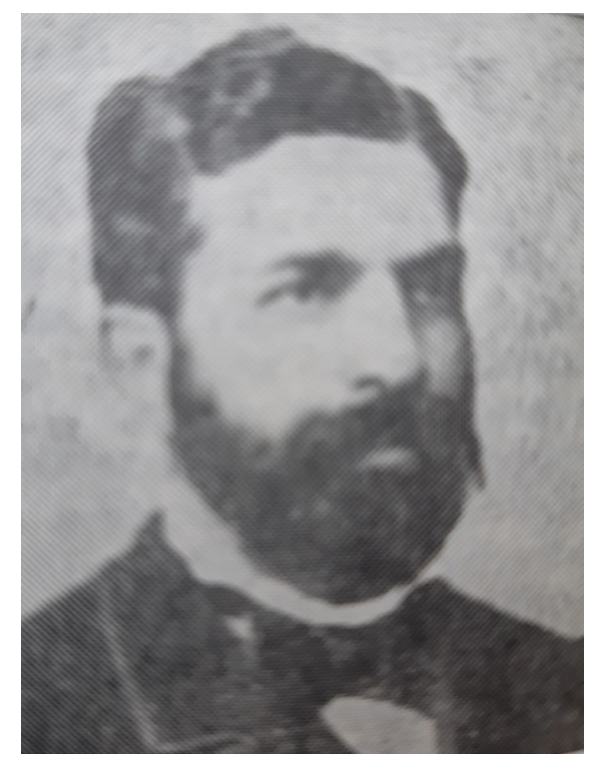

Source: Dicționarul literaturii române. De la origini până la 1900

3. THE EDUCATION OF THE ROMANIAN STUDENTS FROM ABROAD IN THE SECOND HALF OF XIX CENTURY. A STUDY JOURNEY IN SPAIN. VASILE ALEXANDRESCU URECHIA AND THE PROJECT OF THE LATIN WORLD

As I have previously mentioned, it is very well known the fact that, at present, foreign universities were, in the XIX century and even in the first half of XX century, on the first place regarding the education of the cultural and scientific Romanian elites, especially in the case of the teachers from the two universities in the old kingdom of Romania (Iași and Bucharest) ${ }^{7}$.

Of the many types of travel, the study journeys seems to have been quite important and significant, with a programme with well-defined objectives, being made at young ages (20-25 years) where the one who was travelling to study was open to new and knowledge, to other experiences ${ }^{8}$. The mechanism of moving abroad (study journey) from the Romanian

6 Dicționarul literaturii române. De la origini până la 1900, Editura Academiei, București, 1979, pp. 906-907; D. A. Rosetti, Dicționarul contimporanilor, First edition, Editura Lito-Tipografiei Populara, București, 1897, p. 194; M. Bucur, Istoriografia literară românească. De la origini până la G. Călinescu, Editura Minerva, București, 1973, pp. 86-88; Bibliografia românească modernă (1831-1918), vol. IV, (R-Z), general coordination G. Ștrempel, bibliographical coordination L. Angheluță, Editura Academiei Române, București, 1996, pp. 769-770.

7 L. Năstasă, Itinerarii spre lumea savantă..., p. 70; L. Rados, op. cit., p. 37; N. Iorga, O școală nouă istorică. Conferințe ținute la "Liga Culturală", București, 1936, p. 33 (The great Romanian historian showed that in 1936, in the context of the education of the Romanian elite abroad, especially for the years 60-70 of the XIX century, that "before, the important people were educated in school abroad. The school from abroad were much better than the schools from our country, being founded on the work of many free generations").

8 L. Năstasă, op. cit., p. 74. 
space to the West of Europe was clearly established by the Iași historian, Leonidas Rados, who stated in one of his studies that

for the entire modern period, travelling abroad, especially for educational purpose, so that at return one could put your his abilities in the service of community, thus becoming a useful citizen for your country, was one of the episodes which, besides the projection in the ideological space, could radically form the destiny of a young man, building a bright career and sending him straight in the social hierarchy ${ }^{9}$.

Travelling abroad, especially for studies, became "almost a title of glory and fashion", and the Romanian newspapers had extensively presented these study journeys abroad in the middle of the XIX century, both at the departure of the students, during their internship, but also on their return (even if the studies were completed or not by a bachelor or doctoral degree $)^{10}$.

However, the journey always fulfilled a strong function of legitimating the status of a cultivated man, a member of the elite. It was about acquiring references and intellectual, cultural and para-cultural experience of the developed West, either in the form of diplomas, memories, stories or salon relationships ${ }^{11}$.

Thus, when returning from studies abroad, the young people in this category, especially those who came with a diploma, often occupied positions in Romanian education or positions in the state ${ }^{12}$. In general, the purpose of sending young people to study abroad, selected by those who conducted the destiny of Romanian education, was to cover some fields, didactic and social, which contributed directly to the modernisation and good functioning of Romania ${ }^{13}$.

The Romanian scholars abroad (especially those with state funds) were obliged to follow the courses of the chosen institution diligently, to periodically transmit information reports during the studies, and to return to the country to present the diploma obtained in order to show that the resources spent were not wasted or made in vain. The purpose of sending them to study abroad was that they could be used as teachers, which made them interested and motivated to obtain a bachelor or doctoral degree that would allow them to enter an elitist and well-paid body ${ }^{14}$. We mention here that one of the features of the XIX century foreign training courses was their itinerary. Thus, a Romanian student could start his studies in a particular institution and could complete them in another (even in the same city)

9 L. Rados, op. cit., p. 37 (The historian from lași correctly invoking other historiographical opinions showed that study journeys abroad were made from the areas that had a lack under the report of instruction and progress towards the western Europe, this also being valid foe the south-east of Europe and especially for the Romanian space).

10 L. Năstasă, op. cit., p. 86; L. Rados, op. cit., p. 37 (Except the journeys made to obtain a university diploma and which usually involved undergoing an academic stage, for a longer period of time, there have also been shorter study journeys for a semester or more, without aiming to obtain a diploma. L. Năstasă, op. cit., p. 87).

11 Ibidem, pp. 86-87.

12 L. Rados, op. cit., p. 37; L. Năstasă, op.cit., pp. 72, 73, 74.

13 L. Rados, op. cit., p. 42.

14 Ibidem, pp. 43-44, 51, 53, 64 (After the competition through which they obtains the scholar, they had to sign a declaration before they left the country to sign a return order through which they took upon themselves to works as state employees in the specialisation they for a period of time that was twice as long than the one they spent studying). 
being able to go between university centres in the same area (country) or between university centres in Europe. The grants offered by the Romanian state, especially those from the 1860s, were based on this principle: the scholar was even obliged to change two schools in general, one of them being the University of Paris ${ }^{15}$.

Figure 2. Photografy of Vasile Alexandrescu Urechia (1834-1901)

Source: http://enciclopediaromaniei.ro/wiki/Vasile Alexandrescu-Urechia

We did not mention by chance Vasile Alexandrescu Urechia's connections with Spain (especially) and with the other neo-Latin states (in general). Urechia, "probably the most restless Romanian creator of forms and institutions" was the one who initiated a programme which had at its centre the idea of fraternising with the Latin world in order to reach the freedom, national unity and progress objectives. It appears that this programme came to life while V. A. Urechia was in Paris between the years $1853-1857^{16}$. It is a fact that in 1858, on September 25, the Romanian historian published in Madrid in La Discusión, no. 795, an article named Introduction to the History of Romanians in which he supported the unity of the Latin world ${ }^{17}$.

The program was implemented by $\mathrm{V}$. A. Urechia when he returned to Moldova in Iași and after he became the director of the Ministry of Public Instruction in 1859. Thus, in 1860, after the Unification of the Romanian Principalities, he presented his ideas in a speech held in lasi at the end of the school year. On this occasion, V. A. Urechia emphasized the idea of the "juniors"' (young men) study journeys abroad, especially in neo-Latin countries (referring to the universities of France, Italy and even Spain "which represented an instruction terrain that was completely unknown to the Romanians") ${ }^{18}$.

15 L. Rados, op. cit., pp. 38-39.

16 Ibidem, p. 82.

17 D. V. Andronache, op. cit., p. 211. V.A. Urechia's ideas regarding the unity of the Latin world were later retaken on January 281866 by Andrei Vizanti in the newspaper La Reforma (Ibidem, pp. 211-212).

18 L. Rados, op. cit., pp. 82-83. 
Thus, in this context, since 1860, starting with September, through the efforts of V. A. Urechia and with the help of Mihail Kogălniceanu (who was the ad-interim Minister of Public Instruction in Moldova and president of the Council of Ministers) began sending to studies in Italy, at the University of Turin, the first five Romanian scholars ${ }^{19}$. Regarding the issue of sending the Romania young men to study in Spain, only later in the year 1864, on September 25, Andrei Vizanti and Stefan Vârgolici were selected as scholars in letters and sent to Madrid, at the end of the year ${ }^{20}$.

\section{(1865)}

\section{ROMANIAN STUDENTS IN MADRID: ANDREI VIZANTI AND ȘTEFAN VÂRGOLICI}

Coming back to the case of Andrei Vizanti we mention the fact that he enrolled as student of Iași University in the school year 1863-1864 (at Faculty of Law, but also participating in classes at the Faculty of Letters) and after a year of study, in the autumn of the year 1864, he obtained a grant abroad in the field of letters shared between Madrid and Paris as his faculty colleague Ștefan Vârgolici, as I have previously mentioned ${ }^{21}$.

19 Ibidem, p. 83. Although united in 1859 under one state (called United Principalities of Moldavia and Wallachia) by the double election of Alexandru Ioan Cuza, Moldavia and Wallachia had (according to the provisions of the Paris Convention in Paris in August 1858) until the year 1862 (when the ruler completed the institutional and administrative unification), two governments, two Assemblies and two capitals (S. L. Damean, I. Oncescu, O istorie a Românilor de la Tudor Vladimirescu la Marea Unire (1821-1918), Editura Cetatea de Scaun, Târgoviște, 2015, p. 130.

20 L. Rados, "Studenți și profesori ai Universității din Iași la studii în străinătate (deceniul șapte al secolului XIX) (II)", in Historia Universitatis Iassiensis, II, 2011, Editura Univeristății Alexandru Ioan Cuza, Iași, 2010, p. 15.

21 Idem, op. cit., I, pp. 49-51 (Leonidas Rados investigates, among other things, his study of students and university professors from laşi studying abroad in the seventh decade of the XIX century (I-2010, II-2011) and the case of Andrei Vizanti who was a scholar of the Romanian state as a student in Madrid and then a professor at lași University. He quite rightly appreciates, on the basis of his studies, that, as we have seen, there is a great deal of inaccuracies in Romanian historiography regarding academic training and especially the beginning of Andrei Vizanti's teaching career. In order to avoid these inaccuracies, according to Leonidas Rados, more attention should be paid to the corroboration of internal and external sources, we believe we are right and with whom we fully agree. In this context, especially for Andrei Vizanti's studies in Spain (which are the subject of our study), in the Central University, the Faculty of Philosophy and Letters (1865-1868) corroborating the documentary sources at the National Historical Archive of Madrid, Spain, and what has been published in Spanish historiography with documentary sources in the archives in Romania and what has been published in Romanian historiography so far can lead to a better knowledge of the academic years of education and of the activity carried out by Andrei Vizanti as a student in Madrid and to elimination of these inaccuracies). Certain historiographical sources show that Andrei Vizanti began his studies in Madrid in 1866 or that he was a student in Madrid between 1860-1865 (L. Năstasă, Itinerarii spre lumea savantă..., p. 315; Dicționarul literaturii române. De la origini până la 1900..., p. 906; M. Popa, Spania descoperită de români, Editura Dacia, Cluj Napoca, 2007, p. 7), fact invalidated by the unedited documents in the Romanian and Spanish archives (L. Rados, op. cit., p. 50-51; F. J. Juez y Galvez, op.cit., p. 124-125; AHN, Madrid, Universidades, 6887/1). Also in the case of Ștefan Vârgolici, there are some inaccuracies regarding some aspects, being stated that just like Vizanti, he allegedly studied in Madrid between the years 1860-1865 (E. Denize, „Călători români în Spania secolului al XIX-lea”, in Tribuna, serie nouă, an II, nr. 28, 1-15 noiembrie 2003, p. 8). Regarding his studies in Spain it is clear at present that he, as stated by the documentary and historiographical sources, arrived in Madrid together with Andrei Vizanti in 1865 and, it seems that they did not accommodate very well in the capital of Spain and left for Paris (before starting the studies and with the approval of the Romanian authorities), the scholar being, according to some opinions, as the one of Vizanti, awarded/shared for a study in Madrid but also in Paris (AHN, Madrid, Universidades, 6887/1; L. Rados, op. cit., pp. 50-51; F. J. Juez y Galvez also notices in the study dedicated to Andrei Vizanti as a student of the Central University, published in Spain in the year 2003, that, after one mention, only Andrei Vizanti still appears in the documents kept at AHN, Madrid but implies the fact that Ștefan Vârgolici could not continue here the studies and left Spain due to economical reasons 
Practically, at the beginning of 1865 the two scholars of Romania were in the capital of Spain as it can be noticed from the Romanian school statistics and from their correspondence with the Romanian authorities ${ }^{22}$.

In March 1865, Vizanti and Vârgolici were received by the general director of the Ministry of Public Instruction in Spain to whom they presented their recommendation letters from the Minister of Public Instruction n Romanian, and he assured the two Romanian scholars that they would receive all his support ${ }^{23}$.

It was raised the following question, why did the two future Romanian students in Spain need support? Firstly, it in order to enrol in the Central University it was necessary to validate their baccalaureate exam (fact which constituted a problem not only for the Romanian students sent to Paris but also to other European university centres) or the approval to enrol in a university and taking the baccalaureate exam before obtaining the approval. Many times the Romanian students abroad could not validate their baccalaureate exam and they had to retake the exam after private lessons or after attending the same time their university studies together with their secondary studies especially that in that period the baccalaureate exam was taken at the university ${ }^{24}$. As it can be easily noticed from Andrei Vizanti' school documents but also from other documents (correspondence) in the file at the National Historic Archive in Madrid, both he and his colleague had their secondary studies in Moldavia validated/recognised through royal order (March 1865) and they were allowed to enrol in the Faculty of Philosophy and Letters within the Central University, but he, for two years, attended in parallel with the bachelor studies several subjects necessary for the baccalaureate exam which he took in $1867^{25}$.

(financial difficulties) of the young Romanian state, formed in the year 1859. The Spanish researcher notices that although he left from Madrid, Ștefan Vârgolici later distinguished himself as one of the first Romanian Hispanics with a meritorious activity in this sense (F.J. Juez y Galvez, op.cit., p. 125). The great Romanian historian Nicolae Iorga, too, who had as teachers when he was young Andrei Vizanti and Ștefan G. Vârgolici, in Iași, showed that these studied in Madrid as V.A. Urechia. Thus, he mentioned in one of his conferences in 1936, that "Vizanti had learned in Madrid as Urechia (...) Ștefan Vârgolici also learned in Madrid but also in Paris (...) being in the same generation with Andrei Vizanti." He described Andrei Vizanti as a big man, strong, dark haired, with a deep voice who, whenever he took an exam, "rolled a pair of blood-shot eyes" (N. Iorga, op.cit., p. 35). As I have previously mentioned, among these, only Andrei Vizanti had studied in Madrid. V.A. Urechia had visited Spain repeatedly and maintained relationships with the Spanish intellectuals, but he had studied in Madrid, but in Paris (1853-1857), and Ștefan Vârgolici only accompanied Vizanti in Madrid as scholar, in 1865, but after a while he left Spain and continued his studies in France and Germany.

22 L. Rados, op. cit., pp. 50-51; 68-69. F. J. Juez y Galvez showed based on the documentary sources published in his study that the first mentions about the Romanian students in Madrid appeared on March 10 1865 (F. J. Juez y Galvez, op. cit., pp. 124-125). Generally, the young Romanian men who left to study abroad knew each other from Romania, they had been colleagues as it was the case of Vizanti and Vârgolici who lived together during their time in Madrid (until the latter left for Paris) in the same house - L. Rados, "Studenți și profesori ai Universității din Iași la studii în străinătate (deceniul șapte al secolului XIX) (II)", pp. 15, 16.

23 Ibidem, pp. 14, 24 (In the case of many Romanian students sent to study abroad, in order to obtain the support of the local, political or university authorities, they had official letters of recommendation from Romanian so that they could accommodated themselves faster and without incidents. Ibidem, p. 13).

24 Ibidem, p. 23-24.

25 AHN, Madrid, Universidades, 6887/ 1; F. J. Juez y Galvez, op.cit., pp. 125-128; D. V. Andronache, op. cit., pp. 208-209; 214-215, 217. In the royal order issued on March 101865 and transmitted to the director of the Ministry of Public Instruction and to the Rector of the Central University, they are communicated that Mr. Andrei Vizanti and Stefan Vârgolici from the Danubian Principalities were scholars of the Moldo-Wallachian government and they had arrived in Madrid to study at the Faculty of Philosophy and Letters with the objective of broadcasting in their country their knowledge on the Spanish Literature, "thus bringing Romanian closer to the civilisation of other Latin people". Regarding the validation of the baccalaureate of the two Romanians in order to enrol in the classes of the Faculty of Philosophy and Letters, their secondary studies graduation 
As the future Romanian students in Madrid communicated to Bucharest in the first part of the year 1865, about the fact "that the university course" in Spain took five years: two for the baccalaureate exam, two for he bachelor degree and for the doctorate ${ }^{26}$.

But, before enrolling in the Faculty of Philosophy and Letters, the two Romanian scholars had made, after acknowledging the study conditions in Spain, in April 1865, a request towards the Romanian school authorities to move from Madrid to Paris being especially worried that they could not finish their studies in the four years of grant ${ }^{27}$.

In this context and maybe because of this reason, Ștefan Vârgolici ${ }^{28}$ left the capital of Spain (after their request to leave for Paris was approved in May of the same year). Still, in June 1865, Andrei Vizanti gave up his request, probably also as a result of his discussion with his mentor V.A. Urechia, he stayed in Madrid to study especially that he had prepared for the exams and paid the study fees for the first year ${ }^{29}$.

Thus, in September 1865 only Andrei Vizanti enrolled as a student of the Faculty of Philosophy and Letters in Madrid. His application form had been personally made on September 271865 and forwarded to the Rector of the Central University in Madrid being approved on September 28 of the same year by the vice-rector of the institution ${ }^{30}$.

diplomas were recognised and they could enrol in the University, but if they wanted to use their bachelor degree on the territory of Spain they were obliged to revalidated their baccalaureate exam (AHN, Madrid, Universidades, 6887/1; F. J. Juez y Galvez, op.cit., pp. 124-125; D. V. Andronache, op.cit., p. 208). There is no knowledge of the details or motivations for which Andrei Vizanti also followed the required secondary education (for the baccalaureate exam) at Central University in parallel with the bachelor's degree in the years 1865-1867. He may have been forced to attend them to follow the exact steps of the Spanish university education, or he may have done it on his own initiative, although, as shown by the royal order, he was clearly saying that he was obliged to attend high school studies or to revalidate his baccalaureate only if was to be used as a bachelor's degree in Spanish territory.

26 L. Rados, op. cit. p. 24.

27 Ibidem, pp. 30-31 (Vizanti and Vârgolici invoked the fact that in order to obtain the doctorate in Madrid they would have needed a period of five years, as it was stated by the Spanish education system and this period only allowed them to obtain their bachelor degree -the grant was awarded for four years- one fir the study of Spanish language and three for study).

28 Ștefan G. Vârgolici (October 131843 - July 20 1897) —literary critic, translator, professor. He was born in Moldavia, in Borlești (Târgu-Neamț) on October 13 1843. He studied at the Central Gymnasium in lași where he was colleague with Andrei Vizanti. Later, in 1863-1864, Ștefan G. Vârgolici would be colleague with the same Andrei Vizanti at the University of Iași and together with him they would obtain the grant to study abroad in Madrid - the autumn of the year 1864). He did not studied in the capital of Spain, in Madrid, but in Paris and Berlin, but until the end of his life he promoted in Romanian the Spanish culture, being one of those who made the Spanish floklore known in Romania and he was also the first translator in Romania of Cervantes' work, Don Quijote de la Macha (published in the magazine Convorbiri Literare in several parts in the period 1881-1891). He also published several articles of literary criticism, in the same magazine, regarding the work of Miguel de Cervantes, Lope de Vega and Calderon de la Barca. Ștefan G. Vârgolici can be considered the pioneer of the Romania hispanism. After completing his studies in France and Germany, in the year 1875, he came back in Romania and until the end of his life (1897) he was a professor at the University of lași, being the tenure teacher of the department of French language and literature, department which he transformed in the department of the history of modern literature. Besides his didactical activity, he also had an intense activity as a publicist, literary critic and translator. Active member of Junimea Society (1871), he collaborated with the magazine Convorbiri Literare even since its establishment (1867) publishing in its pages, for almost 25 years, translations, literary criticism articles and poems. He rightly can be considered the pioneer of the Romanian hispanism (Dicționarul literaturii române. De la origini până la 1900..., pp. 897-898; D. A. Rosetti, op. cit. p. 192; L. Rados, op. cit. p. 33; E. Denize, Imaginea Spaniei în cultura românească până la primul război mondial, Editura Silex, Bucureşti, 1996, pp. 133; 144-146).

29 L. Rados, op. cit. p. 31.

30 AHN, Madrid, Universidades, 6887/1; F. J. Juez y Galvez, op.cit., pp. 125-126; L. Rados, op. cit. pp. 3334; D. V. Andronache, op. cit., p. 209. 


\section{ANDREI VIZANTI STUDENT IN MADRID (1865-1868)}

Andrei Vizanti stayed in Madrid, Spain, for three years (1865-1868) as a student of the Faculty of Philosophy and Letters of the Central University. During the years of study he was seen as a good student and he obtained extraordinary results in some exams (as also shown in the document issued by the Madrid University in the year 1868 -his academic record - which as present it is at the National Historic Archive in Madrid) ${ }^{31}$, following these efforts he was rewarded in Spain with some prizes ${ }^{32}$, developing in parallel other important activities like the one in the publishing field. Thus, he wrote many articles for the Romanian journalism but also for the Spanish one (in Romania he sent letters for Buletinul Instrucțiunii Publice, Convorbiri Literare, Românul in which he published information regarding the Spanish literature, the Spanish educational system, the organisation of the Museum and the National Library in Madrid, and in Spain he published La Reforma and in La Enseñanza, where he offered the Spanish readers information about the history of Romania). Vizanti visited, during his internship in Madrid, in August-September 1867, and Paris where he sent to Buletinul Instrucțiunii Publice, in the newspaper Românul but also to the Spanish gazette La Enseñanza, letters and also impressions on the preparation of the Universal Exposition in the capital of France ${ }^{33}$.

31 AHN, Madrid, Universidades, 6887/1, (E 797) Andrei Vizanti took 14 exams during his study years in Madrid -1865-1868 (for baccalaureate and bachelor degree). In his first year of study 1865/1866, Andrei Vizanti obtained remarkable results: the score exceptional (sobresalientes) -at the Spanish literature and Greek Novelists exams and the score good (buenos) in Geography and Universal History. In the year 1866 Andrei Vizanti (on August 27) obtains the approval from the general director of the Ministry of Public Instruction, Severo Catalina (after the Romanian student filled an application) and the Rector of the Central University (August 28) to attend at the same time the classes of Classical Greek and Latin Literature and Metaphysics in the school year 1866/1867 so that he could take his baccalaureate exam. On September 26, 1866 Andrei Vizanti (who now appears with his second name - Andrés Vizanti y Basilio) filled just like he did last year an application to enrol in the school year 1866/1867 choosing to study Latin Literature, Greek Literature, Psychology and Logic (for the baccalaureate exam) and the History of Spain and Arabic (for the bachelor degree). On June 3, 1867 Andrei Vizanti made a request towards the Rector of the University of Madrid to take his baccalaureate exam. In June 1867, Andrei Vizanti also took his bachelor degree exams (in 1866/1867) but also the ones necessary for his baccalaureate exam, obtaining the score good (buenos) in Psychology and Logic, the score very good (notable) for the History of Spain, and in Latin Literature, Greek Literature he obtained the score exceptional (sobresalientes). After the Romanian student was examined by a committee lead by Alfredo Camus on June 22, 1867 he was admitted and obtained his baccalaureate diploma which he would receive on October 30 the same year. In his last year of study at the Faculty of Philosophy and Letters of the Central University, 1867/1868, Andrei Vizanti enrolled on September 30, 1867 in the Metaphysics and Ethics, Spanish Literature, History of Spain and Arabic classes, subjects that at the end of the year in 1868, he obtained the score exceptional (sobresalientes). Also see in this sense, F. J. Juez y Galvez, op.cit., pp. 126128; D. V. Andronache, op. cit., pp. 214-215, 217.

32 In the school year 1866/1867, in June 1867 (June 4) Andrei Vizanti enrolled in a competition for a prise in Greek Literature, and as a result of his examination on June 10 of the same year he obtained the score exceptional (sobresalientes) from the examination committee and he would receive the First prize, fact that also became known in Romania (he received the medal in October 1867). During the school year 1867/1868, in June 1868, Andrei Vizanti would win a new prise in Arabic (L. Rados, op. cit. pp. 28-29; F.J. Juez y Galvez, op.cit., p. 128, 129; D. V. Andronache, op. cit., p. 215).

33 L. Rados, op. cit. pp. 33-34; E. Denize, op. cit., pp. 85, 92, 94; L. Năstasă, op.cit., p. 316; See for a part of the articles published by Andrei Vizanti in the year 1866 and 1867, in La Enseñanza especially, La Enseñanza. Revista General de Instrucción Pública, Archivos y Bibliotecas (director Juan Uña), Año II, Madrid, 25 de Agosto de 1866, num. 22, pp. 345-349; Año III, Madrid, 25 Setiembre, 1867, num. 48, pp. 375-377; Año III, Madrid, 10 Noviembre, 1867, num. 51, pp. 41-43; Año III, Madrid, 25 Noviembre, 1867, num. 52, pp. 58-60. For the articles published by Andrei Vizanti in the Romanian and Spanish journalism, their subject and contents, during the study in Madrid (1865-1868) also see D. V. Andronache, op. cit., pp. 209-213; 215-217, 217. 
As a sign of the validation of his activity in April 1868, Andrei Vizanti would be received in Spain in Academia Madritense at the recommendation of Juan Uña (the director of the newspaper La Enseñanza), at a distance of only three months after his mentor V. A. Urechia had been included as member in the same academy, fact that could not be - Leonidas Rados' opinion- just a simple coincidence ${ }^{34}$.

In June of the year 1868, Andrei Vizanti would obtain the title of bachelor of Faculty of Philosophy and Letters within the University of Madrid, after on June 8 he was examined by a committee ${ }^{35}$. The next day, on June 9, 1868, Andrei Vizanti requested a document from the Rector of the Central University a document, an academic record through which hec an prove that he took and passed the bachelor of Arts degree examination, document that was to be sent to the Romanian authorities to obtain the money to pay the 208 scuzi necessary to receive the title ${ }^{36}$. The investiture in the Andrei Vizanti's degree of bachelor of arts of the Faculty of Philosophy and Letters took place on July 31, 1868, but he started many debates in the academic world but also in the Spanish newspapers regarding the oath of the Romanian student. Finally, although he had to make a political and religious oath, according to the Spanish legislation, it was admitted (through royal order) because he was a foreigner to make only the religious one at this graduation ceremony ${ }^{37}$. On the occasion of this investiture, Andrei Vizanti gave a speech named Breve noticia sobre la historia de la Rumanía (Short presentation regarding the History of Romania/ Short presentation on the history of Romania) which was published in Madrid under the form of a brochure ${ }^{38}$.

Andrei Vizanti's work, which has 85 pages is divided into three parts: Dacia and its conquest by the Emperor Traian (pp.10-26), The Romanian nation, its development and the vicissitudes until the beginning of the current century (pp. 26-55), The regeneration and reconstruction of Romania (pp. 56-77), preceded by a geographical description (pp. 7-9) having in the end the Conclusions (pp. 78-81) and General Note (pp.83-85). In the General Note of the work, Vizanti debated the etymology of the word Wallach and he explained the use of the terms Rumanos and Rumania ${ }^{39}$.

34 L. Rados, op. cit. p. 45; Bibliografia românească modernă (1831-1918), vol. IV, (R-Z)..., p. 796 (The speech given by Andrei Vizanti at the inauguration of his Romanian literature course at the Faculty of Letters within the University of lași (published in 1869), also contains "Despre recepțiunea d-lui A. Vizanti la Academia Matritense după extractul ședinței din 29 aprilie 1868/ About the reception of Mr. A. Vizanti at Matritense Academy after the extract of the meeting on April 29 1868."). It is interesting the fact that in the autumn of 1867 and the beginning of 1868, V. A. Urechia was once again in Spain (after he visited Paris) and he definitely met his protégé, Andrei Vizanti (E. Denize, "Călători români în Spania secolului al XIX-lea" in Tribuna...., p. 9; M. Popa, op. cit., p. 8).

35 AHN, Madrid, Universidades, 6887/1; F. J. Juez y Galvez, op.cit., p. 129; L. Rados, op. cit. p. 45.

36 AHN, Madrid, Universidades, 6887/1; F. J. Juez y Galvez, op.cit., pp.129-130; D.V. Andronache, op. cit., p. 217.

37 F. J. Juez y Galvez, op.cit., pp. 131-132; D. V. Andronache, op. cit., pp. 217-218.

38 AHN, Madrid, Universidades, 6887/1 (work published in the brochure, Universidad Central, Facultad de Filosofía y Letras, Breve noticia sobre la Historia de la Rumanía. Discurso leído por Don A. Vizanti en el solemne acto de recibir la investidura de licenciado en la Facultad de Filosofía y Letras, Madrid, Imprenta y estereotipia de M. Rivadeneyra, 1868); F. J. Juez y Galvez, op.cit., pp. 132-133; D. V. Andronache, op. cit., pp. 217-219. The manuscript of Andrei Vizanti's work (mss.1536, p. I, IV, pp. 1-64) who noted on the first page, the title page (I), besides the technical details and the title that was previously mentioned, a motto Veritas Justicia but also the date of June 151868 (which also appears on page 60 together with the name of Andrei Vizanti and Madrid) can be read at the National Library of Spain in digital form (http://bdh rd.bne.es/viewer. vm?id=0000120755\&page=1).

39 AHN, Madrid, Universidades, 6887/1; M. Popa, op. cit., pp. 7- 9; F. J. Juez y Galvez, op.cit., pp. 133-134; D. V. Andronache, op. cit., p. 219. 
It appears that in September 1868, Andrei Vizanti was still in Madrid and he did not leave Romania ${ }^{40}$. As I have shown, after returning in Romania he obtained a position as a professor at the University of lași at the department of Literature and the history of the Romanians in the school year 1868/1869, even occupying his mentor's place V. A. Urechia, university where he also had the position of dean (at the Faculty of Letters) later being named member of the Romanian Academy. His career would end thirty years later in the middle of a scandal emerged from a matter of public funds embezzlement which lead to his emigration in the United States of America (1899), and no one knew anything about him ever since ${ }^{41}$.

\section{CONCLUSIONS}

The universities in France, Germany and Austria, followed in the second plan, by the ones in Belgium, Switzerland, Italy and Hungary had a major role in the education of the Romanian intellectuals from the second half of the XIX ${ }^{\text {th }}$ century and even from the first half of the XXth century, some of them also studying in Spain, Greece and England.

VasileAlexandrescu Urechia militated for the Romanian students to go abroad, especially in the Neo-Latin countries (France, Italy, Spain). Regarding Spain and the intention for the Romanian scholars to study here, he stated, in 1860, that this country was totally unknown to Romanians in terms of instruction/education, noting at the same time, the necessity of existence in the Romanian academic environment of some experts proficient in Spanish language and literature. In this context, a few years later, on September 25, 1864, two students of the University of Iasi, Andrei Vizanti and Ștefan Vârgolici, obtained a scholarship for the field of letters divided between Madrid and Paris. At the beginning of 1865, the two scholars of Romania were in the capital of Spain, but, after a while, in June 1865, Stefan Vârgolici left Madrid and continued his studies in Paris and then in Berlin. Although he has not studied in Spain, he can be considered the initiator of Romanian Hispanism.

Although he had also been tempted to leave for Paris, probably at the advice of his mentor, Vasile Alexandrescu Urechia, in September 1865, Andrei Vizanti became a student of the Faculty of Philosophy and Letters at the Central University and remained here for three years. During the years of studies (1865-1868), he was a meritorious student and obtained special results in some exams (especially in parallel he also passed the exams for the validation of the baccalaureate), while also carrying out an intense publishing activity, writing a series of articles for the press in Romania, but also for the one in Spain. Thus, he

40 F. J. Juez y Galvez, op.cit., p. 134.

41 L. Rados, op. cit. pp. 28-29; D. V. Andronache, op. cit., p. 223; G. Panu, former student of Andrei Vizanti, showed in his memoires on his return to study in Madrid and obtaining a position at University of Iași, also offering details about his first lesson, introductory, of his lecture which he later published in a brochure in 1869 („Principiul unităței în istorie. Discurs rostit la Universitatea din Iași de A. Vizanti, licențiat în filosofie și litere, profesor suplinitor de Istoria și Literatura română, etc., membru al academiei madritene/The principle of the unity in history. Speech given at University of lași by A. Vizanti, bachelor in Philosophy and Letters, substitute teacher of Romanian History and Literature, etc, member of the Academy of Madrid") and which provoked a controversy with Titu Maiorescu because of a small mistake in Latin in his dedication: „Andrei Vizanti, who just came back from Spain where he had completed his university studies (why Spain? Probably because Spain is our Latin sister) immediately asks for a position in the university (...). Vizanti gives his introductory lesson at his lecture talking about: The principle of unity in history (...) The brochure, Vizanti dedicated it in Latin to Ștefan Vârgolici, his high school colleague and colleague at the University of Madrid." (G.Panu, Amintiri dela "Junimea" din Iași, Editura Societății Anonime pe acțiuni Adevărul, București 1908, pp. 342-343; N. Iorga, op.cit., p. 35; A few details about Andrei's emigration/run in the USA and his settlement in the country can be seen in R. Suțu, Iașii de odinioară, Tipografia , "Lumina Moldovei", Iași, 1923, p. 96; N. Leon, Note și Amintiri, „,Cartea Românească”, București, 1933, p. 130. 
sent in Romania correspondence for Buletinul Instrucțiunii Publice (The Newsletter of Public Instruction), Convorbiri Literare (Literary Talks), Românul (The Romanian), making public a series of information regarding the Spanish literature, the Spanish education system, the organisation of the National Museum and Library in Madrid and in Spain he published in the gazette La Reforma and in La Enseñanza, where he offered the Spanish readers information about the history of Romanians.

In June 1868, Andrei Vizanti was to become a graduate of the Faculty of Philosophy and Letters of the Central University, and on July 31 the same year the investiture ceremony took place, but this act provoked more discussions in the academic world as well as in the Spanish press, especially regarding the Romanian student's taking of the oath. Finally, although Vizanti had to take a political and religious oath, according to Spanish law, he was admitted (by royal order), because he was a foreigner, to take only the religious one. On this occasion of the investiture, Andrei Vizanti gave a speech entitled Breve noticia sobre la historia de la Rumanía (Short presentation regarding the history of Romania/ Short information about the history of Romania), speech published in Madrid as a brochure (1868).

After his return to Romania (September-October 1868), Andrei Vizanti obtained, with the support of his mentor, Vasile Alexandrescu Urechia, a position of substitute (temporary) professor at the University of lași for the department of Romanian language, literature and history, starting with the academic year 1868-1869, a position that he will have for almost 30 years. Some of the contemporaries appreciated, that the choice of Madrid and Spain as a study destination for the Romanian scholars in the second half of the XIX ${ }^{\text {th }}$ century, was a whim of Vasile Alexandrescu Urechia, explained by his affinity with the Hispanic culture, but the sending of Andrei Vizanti to study in Madrid and the contact with the Spanish academic environment meant, besides his academic, personal formation, a way of mutual knowledge between Romania and Spain.

To conclude, the presence of the Romanian students in Spain in the second half of the XIXth century was a singular one, constituting an exception of the period, Andrei Vizanti being the only graduate of a Spanish university until the second half of the $X X^{\text {th }}$ century.

\section{BIBLIOGRAPHY}

Andronache D. V. "Contribuția lui Andrei Vizanti la dezvoltarea relațiilor culturale românospaniole", in S. L. Damean, M. Cârstea, M. Damean, L. Dindirică (coords.), Permanențele Istoriei. Profesorului Corneliu Mihai Lungu la 70 de ani, Editura Cetatea de Scaun, Târgoviște, 2013.

Berindei, D., "Spania în viziunea lui Mihail Kogălniceanu şi V. A. Urechia", in Modernitate şi trezire naţională. Cultura naţională modernă. Studii şi eseuri, Editura Fundaţiei PRO, Bucureşti, 2003.

Bibliografia românească modernă (1831-1918), vol. IV, (R-Z), general coordination Gabriel Ștrempel, bibliographical coordination Lucreția Angheluță, preface Gabriel Ștrempel, Romanian Academy Publishing House, Bucharest, 1996.

Bucur, M., Istoriografia literară românească. De la origini până la G. Călinescu Editura Minerva, București, 1973.

Damean, S. L., Oncescu, I., O istorie a Românilor de la Tudor Vladimirescu la Marea Unire (1821-1918), Editura Cetatea de Scaun, Târgoviște, 2015.

Denize, E., Imaginea Spaniei în cultura românească până la primul război mondial, Editura Silex, Bucureşti, 1996.

Denize, E., "Călători români în Spania secolului al XIX-lea", in Tribuna, serie nouă, an II, nr. 28, 2003. 
Dicționarul literaturii române. De la origini până la 1900, Editura Academiei, București, 1979. lorga, N., O școală nouă istorică. Conferințe ținute la "Liga Culturală", București, 1936.

Juez y Gálvez, F.J., "El primer alumno rumano de la Central (1865-1868). 'Acercando así la Romanía á la civilización de las demás naciones latinas'”, in Revista de Filología Románica, 20, 2003.

La Enseñanza. Revista General de Instrucción Pública, Archivos y Bibliotecas (director Juan Uña), Año II, Madrid, 25 de agosto de 1866, num. 22, pp. 345-349; Año III, Madrid, 25 Setiembre, 1867, num. 48, pp. 375-377; Año III, Madrid, 10 de noviembre, 1867, num. 51, pp. 41-43; Año III, Madrid, 25 de noviembre, 1867, num. 52, pp. 58-60.

Leon, N., Note și Amintiri, "Cartea Românească", București, 1933.

Năstasă, L., "Rolul universităţilor occidentale în modernizarea şi europenizarea elitelor româneşti (1860-1918)", in Xenopoliana, VI, nr. 1-2, Iaşi, 1998.

Năstasă, L., Itinerarii spre lumea savantă. Tineri români din spațiul românesc la studii în străinătate (1864-1944), Editura Limes, Cluj Napoca, 2006.

Oncescu, I., România în politica orientală a Franței (1866-1878), Second Edition, revised and amended, Editura Cetatea de Scaun, Târgoviște, 2010.

Oncescu, I., "Cunoaștere și descoperire: Spania în viziunea lui Mihail Kogălniceanu (18461847)", in Ș. Ștefănescu and C. Neagoe (eds.), Cultură, Istorie și Societate, VI, Editura Ars Docendi, Bucuresti, 2017.

Panu, G., Amintiri dela "Junimea" din Iași, Editura Societății Anonime pe acțiuni Adevărul, București, 1908.

Popa, M., Spania descoperită de români, Editura Dacia, Cluj Napoca, 2007.

Rados, L., "Studenți și profesori ai Universității din Iași la studii în străinătate (deceniul șapte al secolului XIX) (I)", in Historia Universitatis Iassiensis, I, 2010, Editura Universității Alexandru Ioan Cuza, Iași, 2010.

Rados, L., "Studenți și profesori ai Universității din Iași la studii în străinătate (deceniul șapte al secolului XIX) (II)", in Historia Universitatis lassiensis, II, 2011, Editura Univeristății Alexandru Ioan Cuza, Iași, 2011.

Rosetti A. D., Dicționarul contimporanilor, First edition, Editura Lito-Tipografiei Populara, București, 1897.

Suțu, R., Iașii de odinioară, Tipografia “Lumina Moldovei”, Iași, 1923.

Vizanti, A., Breve noticia sobre la Historia de la Rumanía. Discurso leído por Don A. Vizanti en el solemne acto de recibir la investidura de licenciado en la Facultad de Filosofía y Letras, Madrid, Imprenta y estereotipia de M. Rivadeneyra, 1868. 